\title{
Origins and trend of radionuclides within the lower Rhône River over the last decades
}

\author{
F. Eyrolle-Boyer ${ }^{1 \star}$, C. Antonelli ${ }^{1}, \mathrm{Ph}$. Renaud $^{1}$ and D. Tournieux ${ }^{2}$ \\ 1 IRSN, PRP-ENV, Laboratoire d'Études Radioécologiques en milieu Continental et Marin, SESURE/LERCM, BP 3, 13115 Saint Paul Lez \\ Durance, France. \\ 2 IRSN, PRP-ENV, Laboratoire de Surveillance et d'Expertise Environnementale par Échantillonnage, SESURE/LS3E, 31 rue de 1'Écluse, \\ BP 35, 78116 Le Vésinet, France.
}

Received 8 April 2013 - Accepted 5 August 2014

\begin{abstract}
Geological and climatic diversity leads to significant spatial variability of naturally occurring radioactivity levels, whether in soils, sediments or natural waters. The activity level of Rhône sediments is estimated at $1450 \mathrm{~Bq} / \mathrm{kg}$, between the levels observed in the Loire $(1925 \mathrm{~Bq} / \mathrm{kg})$ and Seine $(730 \mathrm{~Bq} / \mathrm{kg})$. The largest amounts of radioactive effluent from nuclear facilities concern tritium, for which activity levels are currently 1000 times higher than the sum of artificial gamma emitters discharged. The proportions of naturally occurring ${ }^{14} \mathrm{C}$ and ${ }^{3} \mathrm{H}$ in the lower reaches of the River Rhône are estimated at 50 to $70 \%$ and $<5 \%$, respectively, with the remaining amount coming from nuclear facilities. Long-term records from River Rhône monitoring show that the level of radioactive contamination from artificial sources declined sharply starting in the early 90s, with the level divided by 10 to 100 depending on the element. Radioactivity of natural origin remained unchanged as expected.
\end{abstract}

Keywords: Rhone river / radionuclides / chronicles / suspended particles / filtered waters

\section{Introduction}

The 19 nuclear power plants (NPPs) in France are licensed to discharge low-level, radioactive liquid effluent to aquatic systems, subject to regulations and inspections. The systems concerned are, in descending order of total installed power output: the Channel (15800 MW), the Loire and the Vienne (14500 MW), the Rhône (13400 MW), the Garonne (6 $200 \mathrm{MW})$, the Moselle (5200 MW), the Meuse (2900 MW), the Seine (2600 MW) and the Rhine (1800 MW). In addition to NPPs, the Marcoule spent fuel reprocessing plant, downstream of Tricastin, which has been in the decommissioning phase since 1997, has also discharged waste into the lower reaches of the Rhône since 1958. Over the last two decades, some $20 \%$ of gamma-emitting liquid effluent from the 19 NPPs in France has been discharged into the Channel. Besides the marine environment, more than $60 \%$ of NPP effluent has been discharged into the Rhône (22\%) and the Loire (39\%). Only $1 \%$ of effluent was discharged into the Seine. From the report, it emerges that the Rhône received nearly $65 \%$ of gamma-emitting liquid effluent discharged into the continental aquatic environment by nuclear facilities of all categories. Almost $85 \%$ of this quantity was due to the Marcoule reprocessing centre (Eyrolle, 2009).

The radioactivity of water in the River Rhône has been monitored since the 1960s. Monitoring developed further in the 1970s, in particular with the introduction

\footnotetext{
* frederique.eyrolle-boyer@irsn.fr
}

of systematic gamma spectrometry and tritium analysis methods. Monitoring focuses on two targets: dissolved elements and the particulate fraction, in the first case by analysing filtered water, and in the second through the analysis of settling sludge or suspended matter. One of the sampling stations on the Rhône, located in Vallabrègues, some sixty kilometres from the mouth of the river, was operated initially by the $\mathrm{SCPRI}^{1}$, then by the OPRI ${ }^{2}$ and now by the IRSN. Sampling is carried out there using a "hydro-collector" designed to collect water continuously from the Rhône to obtain monthly samples of filtered water and suspended matter. For more than a decade, the SORA monitoring station in Arles has been used to collect frequent water samples from the Rhône to determine the activity levels of gamma-, beta- and alpha-emitting radionuclides. The Arles monitoring station is located $3.5 \mathrm{~km}$ downstream of the diffluence with the Petit Rhône and $45 \mathrm{~km}$ upstream of the river mouth of the Grand Rhône, that registers $85 \%$ to $90 \%$ of the liquid and solid flows of the River Rhône. By collecting samples of large volumes of water, partially dependent on the flow of passing water and implementing high-performance metrology, the SORA monitoring station allows the detection of artificial radionuclides, now found in trace concentrations, particularly in filtered water from the Rhône (Eyrolle et al., 2010).

\footnotetext{
${ }^{1}$ SCPRI: Central Safety Department for Protection Against Ionising Radiation.

2 OPRI: Office for Protection against Ionising Radiation.
} 
This article shows trends in activity levels due to naturally occurring and artificial radionuclides observed over the last few decades in the lower reaches of the River Rhône.

\section{Results and discussion}

\subsection{Origins and trends of radionuclides in the lower Rhône River over the last few decades}

\subsubsection{Naturally occurring radionuclides}

Most of the naturally occurring radionuclides in the Rhône are drained from soil in the river's drainage basin. These are very long-lived elements which have always been found on Earth: ${ }^{238} \mathrm{U},{ }^{235} \mathrm{U},{ }^{232} \mathrm{Th}$ and ${ }^{40} \mathrm{~K}$ for the most part. The first three decay to produce about thirty decay products or daughter radionuclides with highly variable half-lives, including other isotopes of uranium $\left({ }^{234} \mathrm{U}\right)$ and thorium $\left({ }^{232} \mathrm{Th},{ }^{230} \mathrm{Th}\right.$ and ${ }^{228} \mathrm{Th}$ ), radium isotopes $\left({ }^{226} \mathrm{Ra},{ }^{228} \mathrm{Ra}\right.$ and $\left.{ }^{224} \mathrm{Ra}\right)$, and radioactive isotopes of lead $\left({ }^{210} \mathrm{~Pb}\right.$ in particular). Naturally occurring radionuclides are also formed continuously in the atmosphere as a result of cosmic radiation. These include tritium $\left({ }^{3} \mathrm{H}\right)$, carbon-14 $\left({ }^{14} \mathrm{C}\right)$ and beryllium-7 $\left({ }^{7} \mathrm{Be}\right)$ in particular. These cosmogenic radionuclides are deposited on the surface of the soil, especially by precipitation, and are then drained into the river from soil in the drainage basin. Owing to geological and climatic diversity throughout France, and even at a regional level, natural radioactivity is subject to significant spatial variability and is highly dependent on geology and environmental conditions, whether in soils, sediments or natural water (Picat et al., 2002; Porcelli and Swarzenski, 2003; Pourcelot and Vassas, 2005; Le Roux, 2007). The decay chain of ${ }^{238} \mathrm{U}$ and ${ }^{232} \mathrm{Th}$, respectively, includes 14 and 10 decay products, including ${ }^{226} \mathrm{Ra}$ and ${ }^{210} \mathrm{Po}$ in the first case and ${ }^{228} \mathrm{Ac}$ in the second. As different decay products are never exhaustively quantified at the same time, the assessment of the natural radioactivity of water or sediment is based on the assumption that two elements measured in the same decay chain are at radioactive equilibrium. In this case, the natural radioactivity of water can be approximated by the following equation (1):

$$
\begin{aligned}
\text { Natural radioactivity } & \cong\left[{ }^{40} \mathrm{~K}\right]+\left(14\left[{ }^{238} \mathrm{U}\right]+10\left[{ }^{232} \mathrm{Th}\right]\right) \\
& \cong\left[{ }^{40} \mathrm{~K}\right]+\left(14\left[{ }^{234} \mathrm{~Pa}\right]+10\left[{ }^{228} \mathrm{Ac}\right]\right)
\end{aligned}
$$

This calculation was used to estimate the activity of naturally occurring radionuclides in sediments in the main rivers in France. The results of these calculations show that Rhône sediments exhibit natural radioactivity levels in the region of $1450 \mathrm{~Bq} / \mathrm{kg}$, which is between the values observed in the Loire (1925 Bq/kg) and Seine (730 Bq/kg) (Eyrolle et al., 2008). For comparison, the natural radioactivity of sediments from the Têt, a coastal river in the department of Pyrénées Orientales, west of the Hérault, is between 2000 and $2500 \mathrm{~Bq} / \mathrm{kg}$. These higher natural radioactivity values can be explained by high ${ }^{40} \mathrm{~K}$ concentrations, which are generally an indication of an anthropogenic contribution related to the use of agricultural fertilisers (Ferrand, 2010; Ferrand et al., 2012).

\subsubsection{Artificial radionuclides}

Artificial radionuclides have been released to the environment since the mid-twentieth century through the use of nuclear energy, first for military purposes, then in industry. The artificial radionuclides found in the Rhône today have several origins.

\subsubsection{Persistence from atmospheric fallout}

Total atmospheric fallout from nuclear tests performed between 1945 and 1980 combined with that from the Chernobyl accident has had an impact on environmental radioactivity. For example, the nuclear surface tests carried out between 1945 and 1980 led to an increase in atmospheric tritium concentrations by three orders of magnitude (IAEA, 2012) and those of ${ }^{14} \mathrm{C}$ by about a factor of 2 .

Although most of the short- and medium-lived elements from this fallout have now disappeared as a result of the decay process, residual activity can still be observed in the soil in the Rhône basin, mainly due to ${ }^{137} \mathrm{Cs},{ }^{90} \mathrm{Sr}$ and transuranium long-lived elements $\left({ }^{238} \mathrm{Pu},{ }^{239+240} \mathrm{Pu}\right.$ and $\left.{ }^{241} \mathrm{Am}\right)$ (Perkins and Thomas, 1980; Duffa, 2001; Renaud et al., 2004). Soil erosion and draining processes lead to the transfer of these artificial radionuclides to river water in dissolved form and/or bound to solid particles. Since the early 1990s and the sharp decline in the discharge of liquid effluent from nuclear facilities along the Rhône, the presence of artificial radionuclides in the river via its drainage basin has represented a considerable and, in some cases, predominant source term. This is the case in particular of ${ }^{137} \mathrm{Cs}$ and plutonium isotopes when the river is in flood (Eyrolle et al., 2006; Rolland et al., 2006). It is also the case of ${ }^{14} \mathrm{C}$, where terrigenous contributions would seem to account for 50 to $70 \%$ of the annual average activity recorded in the lower Rhône (Eyrolle-Boyer et al., 2012). It is estimated, however, that less than $5 \%$ of the annual average free tritium (HTO) activity in the lower Rhône is attributable to the drainage basin, with effluent from the nuclear industry accounting for most of this activity (Eyrolle-Boyer et al., 2013).

\subsubsection{Liquid effluent from nuclear facilities}

The main source terms in the Rhône valley are the Marcoule industrial site and the Bugey, Saint-Alban, Cruas and Tricastin nuclear power plants and, to a lesser extent, the Pierrelatte site and the Creys-Malville site, which is currently undergoing deconstruction.

Tritium represented the greatest amount of effluent discharged by nuclear facilities, with a total activity of $287 \mathrm{TBq}$ in 2010, all types of facilities considered. Excluding ${ }^{14} \mathrm{C}$, the activity of the other radionuclides discharged into the Rhône (for the most part ${ }^{58} \mathrm{Co},{ }^{60} \mathrm{Co},{ }^{63} \mathrm{Ni},{ }^{90} \mathrm{Sr},{ }^{106} \mathrm{Ru},{ }^{125} \mathrm{Sb},{ }^{110 \mathrm{~m}} \mathrm{Ag}$ and ${ }^{137} \mathrm{Cs}$ ) totalled $125 \mathrm{GBq}$ in 2010 , which is about 2000 times less than the activity of tritium discharge alone; ${ }^{14} \mathrm{C}$ releases from nuclear industries (excluding Marcoule discharges) being of the same order of magnitude (149 GBq in 2010) (Fig. 1).

While most of the tritium observed came from nuclear power plants, the Marcoule site was responsible for $95 \%$ of activity due to other radionuclides. 


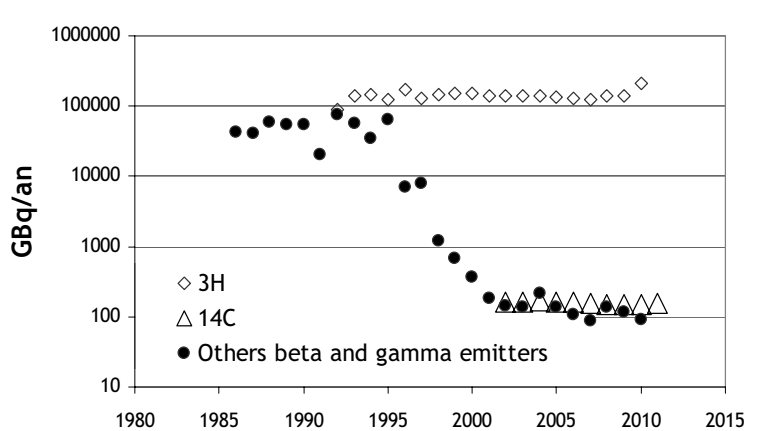

Fig. 1. Records of activity levels for tritium, ${ }^{14} \mathrm{C}$ and other radionuclides (in $\mathrm{GBq} /$ year) discharged into the River Rhône.

A considerable decline in the quantities of radionuclides discharged to the river has been observed over the last two decades (Fig. 2). The most significant downturns were observed starting in 1990, when a new plant was opened to treat liquid effluent from the Marcoule site and again in 1997, when spent fuel reprocessing came to an end in Marcoule.

The isotopic composition of effluent has considerably changed over time, especially effluent from Marcoule and, to a lesser extent, nuclear power plants. This change is mainly due to the quality of reprocessed fuel and waste treatment methods. Between 1975 and 1990, ${ }^{106} \mathrm{Ru}$ was by far the most abundant gamma-emitting radionuclide contained in liquid effluent from the Marcoule site. At present, ${ }^{90} \mathrm{Sr},{ }^{137} \mathrm{Cs}$ and ${ }^{60} \mathrm{Co}$ account for $90 \%$ of the activity discharged by the site (Eyrolle and Renaud, 2012; Eyrolle-Boyer et al., 2012). After tritium, which represented more than $95 \%$ of radioactive effluent, the principal radionuclides discharged by nuclear power plants were ${ }^{58} \mathrm{Co}(22 \%),{ }^{110 \mathrm{~m}} \mathrm{Ag}$ and ${ }^{60} \mathrm{Co}(21 \%)$, and ${ }^{63} \mathrm{Ni}(17 \%)$.

\subsubsection{Hospital waste}

A number of medical centres using nuclear sources for diagnosis and treatment purposes are located along the Rhône and some of its tributaries. Discharge from these centres contains very short-lived radionuclides, of which only iodine-131 $\left({ }^{131} \mathrm{I}\right)$ is regularly measured in the Rhône.

\subsubsection{Recent significant events - atmospheric fallout in France from the Fukushima accident}

The accident at the Fukushima NPP in Japan led to an extremely small amount of fallout in France, observed mostly between mid-March and early May 2011, and equivalent to about one-thousandth of the fallout in France from the Chernobyl accident. The analysis of the impact of the Fukushima accident in France based on the results of reinforced environmental radioactivity monitoring was summarised in the IRSN report IRSN/DEI/2011-01 (Collectif DEI, 2011). No significant observations could be made of the impact of the Fukushima accident in French rivers, either because the related activity levels were too low, or because they were masked by activity due to discharge from nuclear facilities $\left({ }^{134} \mathrm{Cs}\right.$ and $\left.{ }^{137} \mathrm{Cs}\right)$, by residual activity from the Chernobyl accident $\left({ }^{137} \mathrm{Cs}\right)$, or by hospital waste, as in the case of ${ }^{131} \mathrm{I}$, which was the most abundant radionuclide observed in the air and in food after the accident. By the end of spring 2011, any ${ }^{131}$ I resulting from the Fukushima accident had completely disappeared from all compartments of the environment in France, owing to its short radioactive half-life of 8 days. It is worth noting that during annual radioecological monitoring studies conducted in 2011 and $2012,{ }^{134} \mathrm{Cs}$, which had disappeared from the environment for several years, was nevertheless detected in several samples of bryophytes, which are aquatic mosses considered as good bioindicators, at levels very close to quantification thresholds (Claval et al., 2012), probably attesting to some inputs from the Fukushima accident into French aquatic systems.

\subsection{Activity levels measured over the last few decades}

Environmental monitoring records show that while natural radioactivity has obviously remained stable over time, contamination levels in the River Rhône began to decline sharply in the early 1990s, being divided by 10 to 100 according to the radionuclide concerned. This can be explained by the reduced amounts of liquid effluent from the Marcoule site, as demonstrated in Figure 2.

Whatever their origin, radionuclides were found in the dissolved phase (filtered water) or the particulate phase (suspended matter), depending mainly on their chemical properties; in other words, on their ability to bind to solid suspended particles or be deposited as sediment (Eyrolle and Charmasson, 2001, 2004; Filella et al., 2002; Rolland et al., 2006). Monitoring records revealed changes in activity levels in both these phases.

\subsubsection{Activity levels measured in filtered water}

\subsubsection{Naturally occurring radionuclides}

${ }^{40} \mathrm{~K}$ and the various elements in the ${ }^{238} \mathrm{U}$ and ${ }^{232} \mathrm{Th}$ decay chains, such as ${ }^{234} \mathrm{~Pa}$ and ${ }^{228} \mathrm{Ac}$, accounted for most of the natural radioactivity in the River Rhône (Fig. 3). ${ }^{7} \mathrm{Be}$, a short-lived (53 days) cosmogenic radionuclide was observed at activity concentrations that were significantly lower and more variable than those of various telluric radionuclides. The activity of this radionuclide in water largely depends on the age of the water mass in transit and on precipitation over the drainage basin. The activity levels of ${ }^{22} \mathrm{Na}$, another cosmogenic radionuclide, were an order of magnitude lower.

As expected, the activity levels of naturally occurring radionuclides measured in filtered water from the lower Rhône were stable over time (on a human scale), and consequently the same as values recorded in previous years. This was the case for naturally occurring radionuclides routinely measured by gamma spectrometry, such as those shown in Figure 3. It was also the case, however, for naturally occurring isotopes that are not investigated on a routine basis, but that can be quantified by isotopic analysis. These include in particular ${ }^{226} \mathrm{Ra},{ }^{228} \mathrm{Ra}$, ${ }^{230} \mathrm{Th},{ }^{232} \mathrm{Th}$ and ${ }^{234} \mathrm{U}$.

Natural radioactivity measured in filtered water throughout France was in the region of a few hundred $\mathrm{mBq} / \mathrm{L}$. On the whole, this natural radioactivity was distributed almost equally among ${ }^{40} \mathrm{~K}$ and the ${ }^{238} \mathrm{U}$ and ${ }^{232} \mathrm{Th}$ decay chains, both in the 


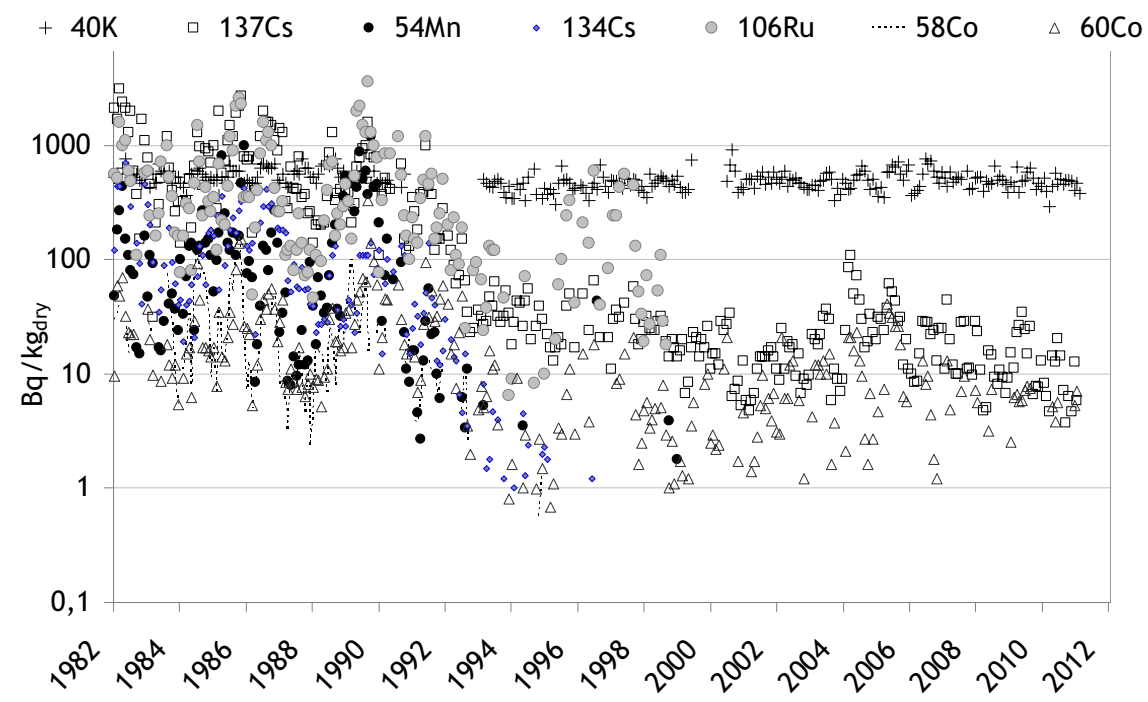

Fig. 2. Records of activity levels measured in suspended matter in the lower Rhône over the last few decades (Vallabrègues monitoring station). Since the beginning of the 21 st century, only the artificial radionuclides ${ }^{137} \mathrm{Cs}$ and ${ }^{60} \mathrm{Co}$ have been routinely detected by gamma spectrometry at this station.

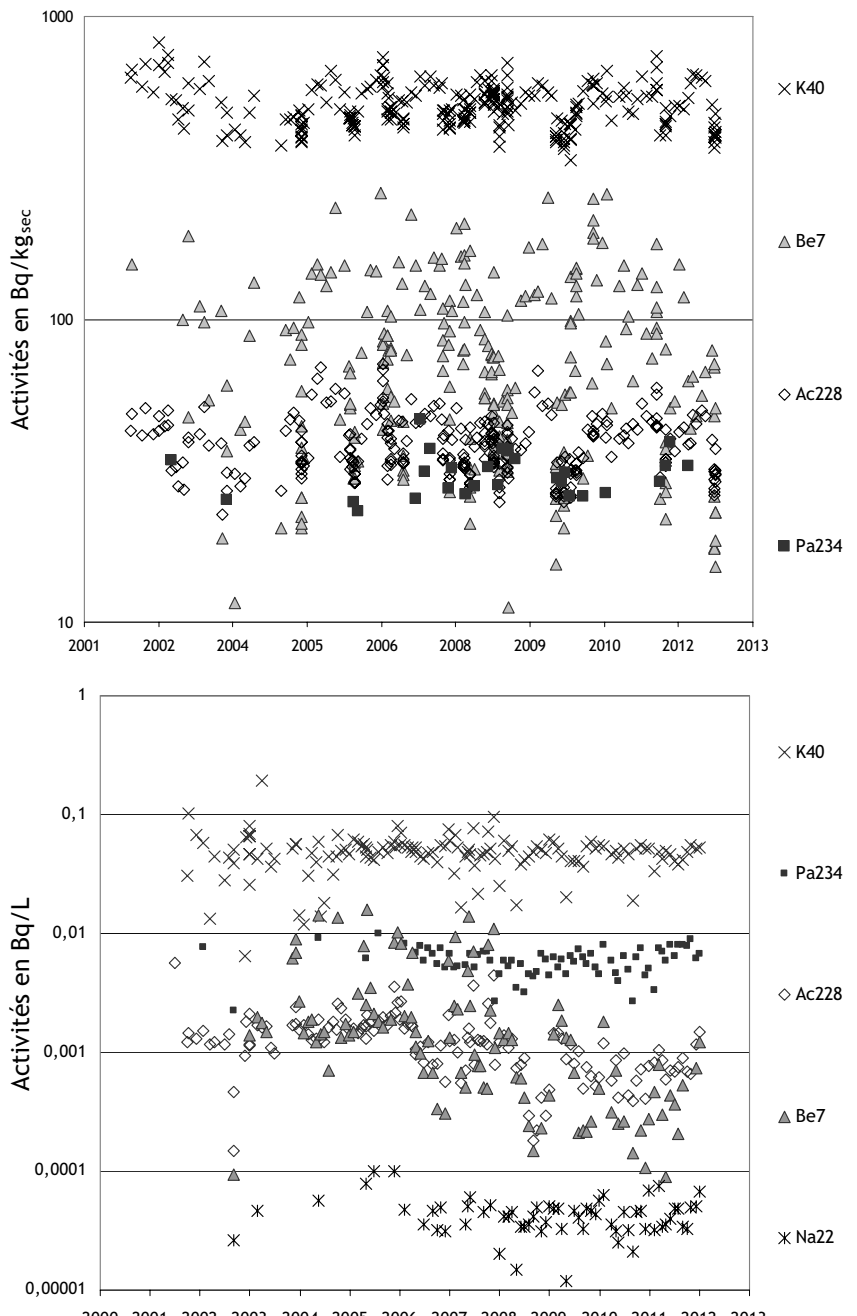

20002001200220032004200520062007200820092010201120122013

Fig. 3. Record of activity levels for the main naturally occurring radionuclides measured in suspended matter (top) and filtered waters (bottom) in the lower Rhône; 2002-2012.
Table 1. Detection frequency of artificial radionuclides in filtered water in 2012 (only radionuclides that were detected at least once are included).

\begin{tabular}{|cc}
\hline Radionuclide & Detection frequency in $\mathbf{2 0 1 0}$ \\
\hline${ }^{137} \mathrm{Cs}$ & $100 \%$ \\
${ }^{90} \mathrm{Sr}$ & $100 \%$ \\
${ }^{3} \mathrm{H}$ & $100 \%$ \\
${ }^{239+240} \mathrm{Pu}$ & $100 \%$ \\
${ }^{241} \mathrm{Am}$ & $100 \%$ \\
${ }^{60} \mathrm{Co}$ & $92 \%$ \\
${ }^{238} \mathrm{Pu}$ & $69 \%$ \\
${ }^{124} \mathrm{Sb}$ & $55 \%$ \\
${ }^{125} \mathrm{Sb}$ & $25 \%$ \\
${ }^{58} \mathrm{Co}$ & $25 \%$ \\
${ }^{131} \mathrm{I}$ & $8 \%$ \\
\hline
\end{tabular}

dissolved phase (drinking water) and the particulate phase (suspended matter and sediments). In the River Rhône, the proportion of naturally occurring ${ }^{14} \mathrm{C}$ was between 50 and $70 \%$. The proportion of naturally occurring tritium, however, was very small compared with artificial contributions $(<5 \%$ on average) (Eyrolle-Boyer et al., 2012).

\subsubsection{Artificial radionuclides}

Of the artificial radionuclides targeted in $2012,{ }^{137} \mathrm{Cs},{ }^{90} \mathrm{Sr}$, ${ }^{3} \mathrm{H},{ }^{239+240} \mathrm{Pu},{ }^{241} \mathrm{Am},{ }^{60} \mathrm{Co},{ }^{238} \mathrm{Pu},{ }^{124} \mathrm{Sb},{ }^{125} \mathrm{Sb},{ }^{58} \mathrm{Co}$ and ${ }^{131} \mathrm{I}$, listed in decreasing order of detection frequency, were detected in filtered water from the lower Rhône (Tab. 1). Systematic searches were not conducted for ${ }^{3} \mathrm{H}$ and ${ }^{14} \mathrm{C}$. They can, however, be detected in the river by searching for them using certain analysis techniques. Searches were carried out for extremely low levels of transuranium elements $\left({ }^{239+240} \mathrm{Pu},{ }^{238} \mathrm{Pu},{ }^{241} \mathrm{Am}\right.$ and $\left.{ }^{244} \mathrm{Cm}\right)$ in environmental samples using alpha spectrometry measurements. They were almost always quantified (detected). For ${ }^{3} \mathrm{H}$, activity levels varied from $5.6 \pm 0.4 \mathrm{~Bq} / \mathrm{L}$ to $10.4 \pm 0.3 \mathrm{~Bq} / \mathrm{L}$, for ${ }^{90} \mathrm{Sr}$ 
from $0.00062 \pm 0.00002 \mathrm{~Bq} / \mathrm{L}$ to $0.0019 \pm 0.00002 \mathrm{~Bq} / \mathrm{L}$, and for ${ }^{137} \mathrm{Cs},{ }^{124} \mathrm{Sb},{ }^{125} \mathrm{Sb},{ }^{58} \mathrm{Co}$ and ${ }^{131} \mathrm{I}$ from $0.000019 \pm$ $0.000002 \mathrm{~Bq} / \mathrm{L}$ to $0.00052 \pm 0.00001 \mathrm{~Bq} / \mathrm{L}$. Activity levels for transuranium elements $\left({ }^{239+240} \mathrm{Pu},{ }^{238} \mathrm{Pu},{ }^{241} \mathrm{Am}\right.$ and $\left.{ }^{244} \mathrm{Cm}\right)$ were between one and more than three orders of magnitude lower than the last-mentioned range (Fig. 3).

The detection frequencies and activity ranges for artificial radionuclides observed in 2010 were similar to those recorded in previous years.

Over the period 2002-2012, activity concentrations for all artificial radionuclides measured in filtered water from the lower Rhône tended to decrease by a factor of 5 to 10, except for tritium and ${ }^{131} \mathrm{I}$, for which activity concentrations remained relatively stable.

Over the same period (2002-2012), HTO (tritiated water) activity levels were around $10 \mathrm{~Bq} / \mathrm{L}$ (from $1.0 \pm 0.7 \mathrm{~Bq} / \mathrm{L}$ to $19.4 \pm 1.1 \mathrm{~Bq} / \mathrm{L}$ of combustion water, with an average of $5.6 \pm 4.8$ over the period 2010-2011), while activity levels for other artificial and naturally occurring radionuclides fell short of $1 \mathrm{mBq} / \mathrm{L}$ (Fig. 5). Activity levels for ${ }^{14} \mathrm{C}$ in the lower Rhône were estimated at $0.004 \mathrm{~Bq} / \mathrm{L}$ (for an average carbon concentration of $20 \mathrm{mg} / \mathrm{L}$ ), i.e. ten times higher than those for ${ }^{90} \mathrm{Sr}$, an artificial beta-emitting radionuclide that is predominant in the lower Rhône (Eyrolle-Boyer et al., 2012).

\subsubsection{Activity levels measured in suspended matter}

\subsubsection{Naturally occurring radionuclides}

As observed with filtered water, ${ }^{40} \mathrm{~K}$ and the various elements in the ${ }^{238} \mathrm{U}$ and ${ }^{232} \mathrm{Th}$ decay chains, such as ${ }^{234} \mathrm{~Pa}$ and ${ }^{228} \mathrm{Ac}$, accounted for most of the natural radioactivity measured in the River Rhône (Fig. 3). Specific activity levels for ${ }^{7} \mathrm{Be}$, a short-lived cosmogenic radionuclide with a half-life of 53 days, were significantly higher than those of other elements in the uranium/thorium decay chains. This element made a significant contribution to the natural radioactivity of particles transiting in the river. As in the case of filtered water, activity levels for ${ }^{7} \mathrm{Be}$ varied quite widely as they depend on the age of water and sediment "mass" in transit, as well as on precipitation over the drainage basin. ${ }^{22} \mathrm{Na}$, which was found in filtered water, was not detected in suspended matter, because sodium is mostly found in dissolved form in continental water systems (Fig. 3).

As observed in filtered water, activity levels for naturally occurring radionuclides measured in suspended matter in the lower Rhône, in this case by gamma spectrometry, were stable over time and on the scale of observation concerned here, and were consequently the same as values recorded in previous years. Attention should, however, be drawn to seasonal variations in activity levels for some telluric elements, such as those observed here for ${ }^{228} \mathrm{Ac}$. These are directly related to the types of minerals in transit, which depend on hydrology (Laubenstein and Magaldi, 2008; Eyrolle et al., 2012).

\subsubsection{Artificial radionuclides}

Artificial radionuclides routinely sought and detected in 2012 in suspended matter in the lower Rhône

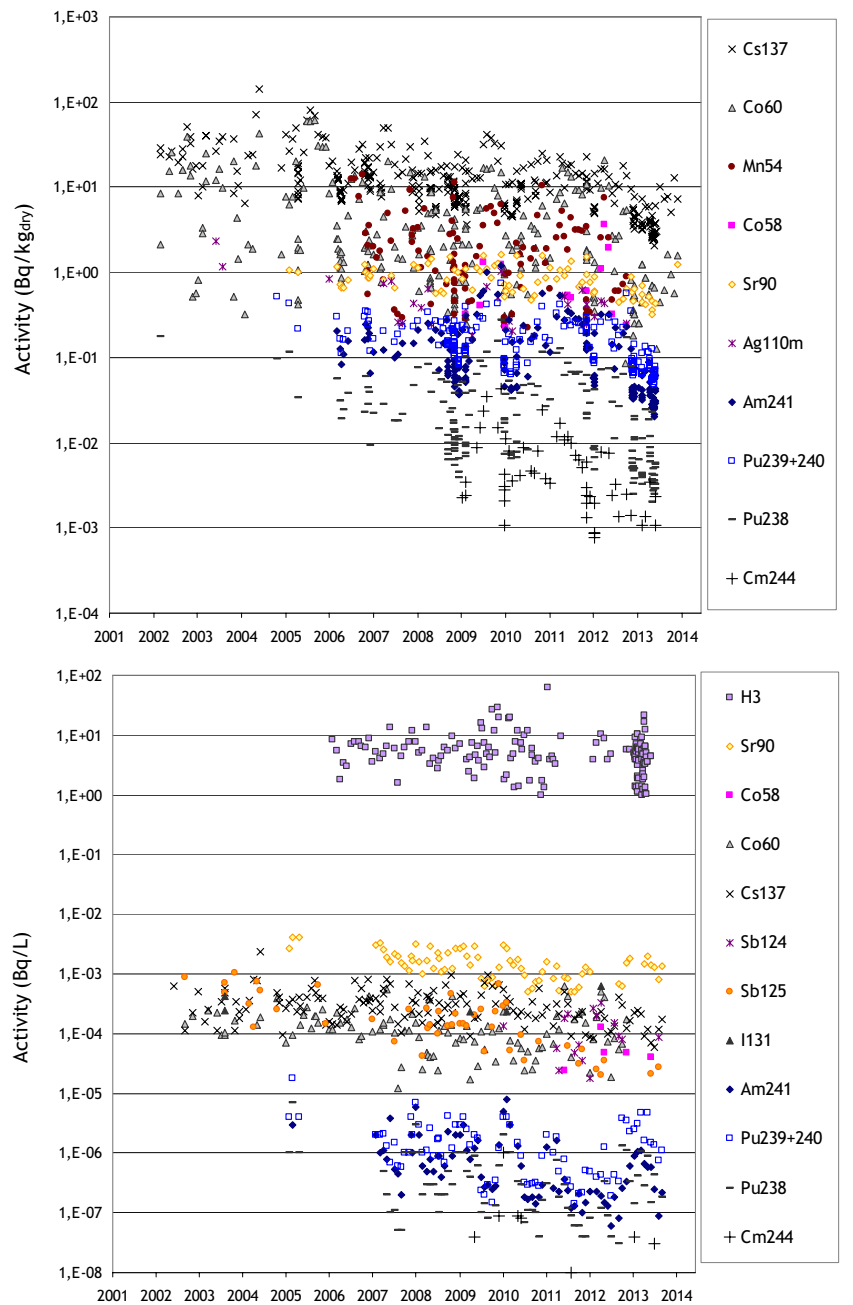

Fig. 4. Record of activity levels for the artificial radionuclides detected in suspended matter (top) and filtered waters (bottom) in the lower Rhône; 2002-2012.

were, in decreasing order of detection frequency, ${ }^{137} \mathrm{Cs}$, ${ }^{239+240} \mathrm{Pu},{ }^{241} \mathrm{Am},{ }^{238} \mathrm{Pu},{ }^{60} \mathrm{Co},{ }^{90} \mathrm{Sr},{ }^{244} \mathrm{Cm},{ }^{54} \mathrm{Mn},{ }^{58} \mathrm{Co}$ and ${ }^{110 \mathrm{~m}} \mathrm{Ag}$. As was the case with filtered water, transuranium elements $\left({ }^{239+240} \mathrm{Pu},{ }^{238} \mathrm{Pu},{ }^{241} \mathrm{Am}\right.$ and $\left.{ }^{244} \mathrm{Cm}\right)$ were measured by alpha spectrometry following radiochemical extraction and purification. They were detected at extremely low levels in suspended matter in water and very regularly quantified (Tab. 2). As in previous years, ${ }^{137} \mathrm{Cs}$ was the predominant artificial radionuclide measured in suspended matter (Fig. 4). Its specific activity varied from $3.2 \pm 0.4 \mathrm{~Bq} / \mathrm{kg}_{\text {dry }}$ to $16.5 \pm$ $1.6 \mathrm{~Bq} / \mathrm{kg}_{\text {dry }}$. Activity levels for other artificial radionuclides, measured by gamma spectrometry $\left({ }^{60} \mathrm{Co},{ }^{54} \mathrm{Mn},{ }^{58} \mathrm{Co}\right.$ and ${ }^{110 \mathrm{~m}} \mathrm{Ag}$ ) or following beta radiochemistry $\left({ }^{90} \mathrm{Sr}\right)$ were up to two orders of magnitude lower. Note that activity levels for ${ }^{14} \mathrm{C}$, a radionuclide of partly artificial origin, were higher than those of other artificial radionuclides and varied from $111 \pm 2$ to $294 \pm 2 \mathrm{~Bq} / \mathrm{kg} \mathrm{C}$ (Fig. 5). Specific activity levels for transuranium elements $\left({ }^{239+240} \mathrm{Pu},{ }^{238} \mathrm{Pu},{ }^{241} \mathrm{Am}\right.$ and $\left.{ }^{244} \mathrm{Cm}\right)$ were between $0.001 \mathrm{~Bq} / \mathrm{kg}_{\text {dry }}$ and $0.1 \mathrm{~Bq} / \mathrm{kg}_{\text {dry }}$, i.e. lower than the above ranges of values. During the second half of 2012, 

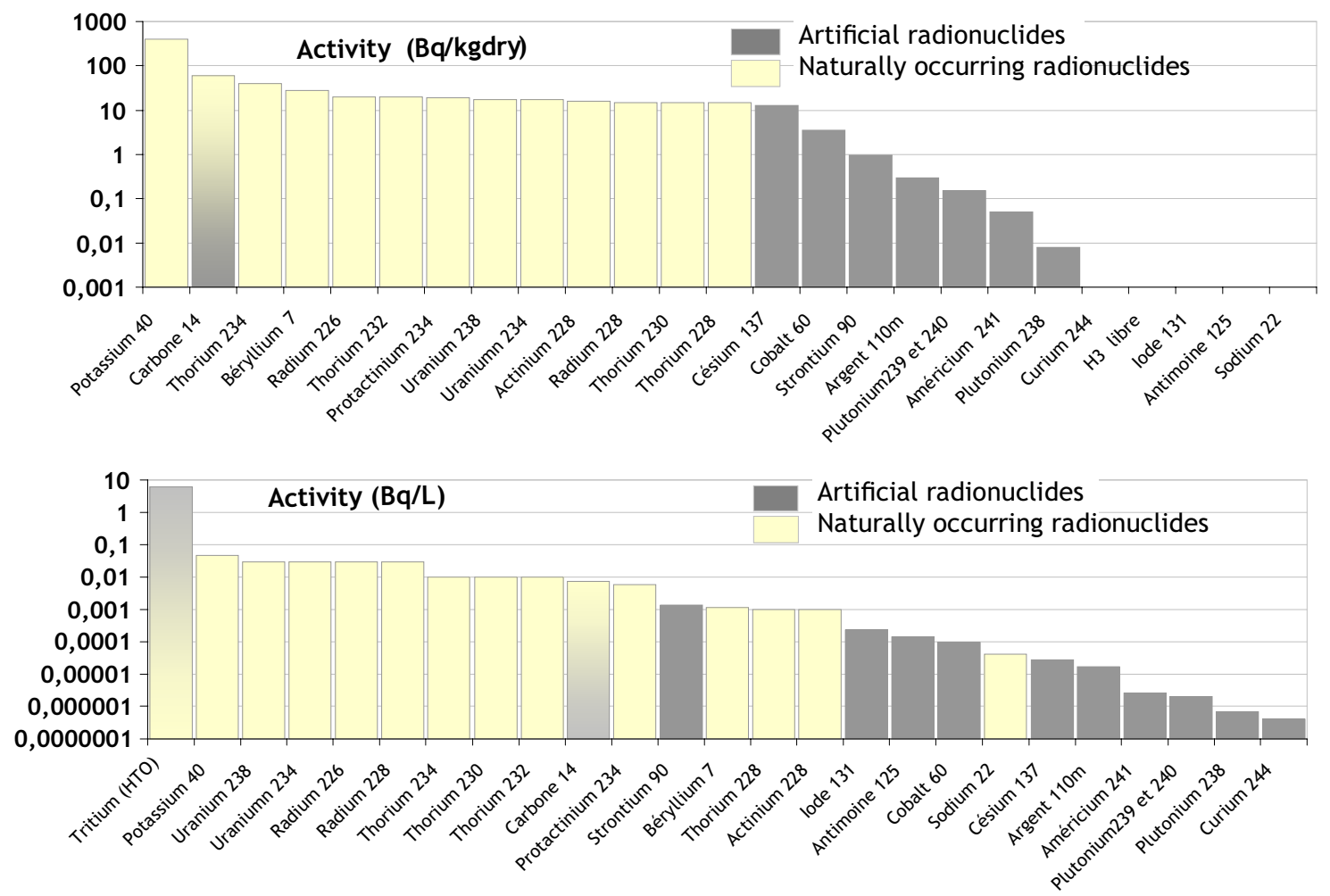

Fig. 5. Activity levels of the main naturally occurring and artificial radionuclides detected in suspended matter (top) and in filtered water (bottom) in the lower Rhône: SORA Station (2002-2012); tritium, iodine-131, antimony-125 and sodium-22 are elements that almost never bind to particles.

Table 2. Detection frequency of artificial radionuclides in suspended matter in 2012 (only radionuclides that were detected at least once are included).

\begin{tabular}{cc}
\hline Radionuclide & Detection frequency in $\mathbf{2 0 1 2}$ \\
\hline${ }^{137} \mathrm{Cs}$ & $100 \%$ \\
${ }^{239+240} \mathrm{Pu}$ & $100 \%$ \\
${ }^{238} \mathrm{Pu}$ & $100 \%$ \\
${ }^{241} \mathrm{Am}$ & $100 \%$ \\
${ }^{60} \mathrm{Co}$ & $97 \%$ \\
${ }^{90} \mathrm{Sr}$ & $78 \%$ \\
${ }^{244} \mathrm{Cm}$ & $38 \%$ \\
${ }^{54} \mathrm{Mn}$ & $32 \%$ \\
${ }^{58} \mathrm{Co}$ & $18 \%$ \\
${ }^{110 \mathrm{~m}} \mathrm{Ag}$ & $11 \%$ \\
\hline
\end{tabular}

activity ranges for some artificial radionuclides, especially ${ }^{54} \mathrm{Mn}$ and ${ }^{60} \mathrm{Co}$, appeared significantly lower than those observed earlier in the year or in previous years. High-water levels in the Rhône generally led to a drop in the specific activity of most artificial radionuclides. This can be largely explained by the dilution of suspended matter contaminated by industrial discharge with telluric particles that are less contaminated, if at all (Eyrolle et al., 2012). This trend cannot be explained solely by the floods in autumn 2012, as relatively low levels were also recorded outside this period.
Over the period 2002-2012, activity concentrations for all artificial radionuclides measured in suspended matter tended to decrease by a factor of 5 to 10 in most cases, as seen in filtered water (Fig. 4).

Most radioactivity in suspended matter in the lower Rhône was of natural origin. Levels for carbon-14, which is partly artificial in origin, were higher than the great majority of natural radionuclides (Fig. 5).

Lastly, it should be noted that the contribution of suspended matter to the overall radioactivity of river water, whether natural or anthropogenic, is of course dependent on the suspended load, particularly the river's rate of flow. In the lower Rhône, the suspended load increased by a factor of about 10 when the rate of flow increased from 2000 to $6000 \mathrm{~m}^{3} / \mathrm{s}$, thus modifying the proportions of radionuclides in transit in the dissolved and particulate phases (Antonelli, 2008, 2010, 2011, 2013).

\section{Conclusions}

Since the middle of the last century, nuclear facilities located in the Rhône valley have discharged low-level radioactive liquid effluent into the River Rhône.

The SORA monitoring station in Arles, located $45 \mathrm{~km}$ upstream of the mouth of the Grand Rhône, has continuously collected samples of large volumes of water to detect any trace concentrations of artificial radionuclides. The station 
supplements the network that was set up along the Rhône corridor from the mid-1970s, to monitor the water in the River Rhône.

The resulting records show that the activity levels of artificial radionuclides in the Rhône, whether in the dissolved or particulate phase, have tended to decline, including over the last ten years. As expected, activity concentrations of naturally occurring radionuclides are stable over time (on a human scale).

Our research highlights the fact that most of the radioactivity in the River Rhône is of natural origin. However, tritium, of which a considerable proportion in the lower Rhône is due to nuclear industrial effluent, is the predominant radionuclide in filtered water. The same is true for ${ }^{14} \mathrm{C}$ regarding suspended matter.

Acknowledgements. The authors would like to express their sincere thanks to the Agence de l'Eau Rhône Méditerranée Corse for providing financial support for the SORA station and to the Observatoire des Sédiments du Rhône (OSR) of the Zone Atelier Bassin du Rhône (ZABR), the recipient of this summary report.

\section{References}

Antonelli C. (2008) Flux de radioactivité exportés par le Rhône en Méditerranée en 2007, Station Observatoire du Rhône en Arles (SORA), Report DEI/SESURE/2008-35.

Antonelli C. (2010) Flux de radioactivité exportés par le Rhône en Méditerranée en 2008, Station Observatoire du Rhône en Arles (SORA), Report DEI/SESURE/2010-04.

Antonelli C. (2011) Flux de radioactivité exportés par le Rhône en Méditerranée en 2009, Station Observatoire du Rhône en Arles (SORA), Report DEI/SESURE/2011-25.

Antonelli C. (2013) Flux de radioactivité exportés par le Rhône en Méditerranée en 2010 et 2011, Station Observatoire du Rhône en Arles (SORA), Report PRP-ENV/SESURE/2013-03.

Claval D., Antonelli C., Pommier J., Theureau L. (2012) Suivi radioécologique 2011 des CNPE francais, Report PRPENV/SESURE/2012-04.

Collectif DEI (2011) Analyse de l'impact de l'accident de Fukushima en France (métropole et DROM-COM) à partir des résultats de la surveillance renforcée de la radioactivité de l'environnement, Report IRSN/DEI/2011-01, 90p.

Duffa C. (2001) Répartition du plutonium et de l'américium dans l'environnement terrestre de la basse vallée du Rhône, thèse de doctorat, rapport CEA-R-5977.

Eyrolle F. (2009) Chronique des niveaux d'activité au sein des systèmes aquatiques fluviaux français - Radionucléides émetteurs gamma, ${ }^{90} \mathrm{Sr}$ et isotopes du plutonium, Rapport IRSN/DEI/SESURE 2009-29.

Eyrolle F., Charmasson S. (2001) Distribution of organic carbon, selected stable elements and artificial radionuclides among dissolved, colloidal and particulate phases in the Rhône River (France): Preliminary results, J. Environ. Radioact. 55, 145-155.

Eyrolle F., Charmasson S. (2004) Importance of colloids in the transport within the dissolved phase $(<450 \mathrm{~nm})$ of artificial radionuclides from the Rhône River towards the Gulf of Lions (Mediterranean Sea), J. Environ. Radioact. 72 (3), 273-286.

Eyrolle F., Rolland B., Antonelli C., Métivier J.M. (2006) Artificial radioactivity within the Rhône River waters - Consequences of floods on activity levels and fluxes toward the Sea, Environnement Risques et santé 5 (2), 83-92.

Eyrolle F., Claval D., Gontier G., Antonelli C. (2008) Radioactivity level in major French rivers: summary of monitoring chronicles acquired over the past thirty years and current status, J. Environ. Monitoring 10, 800-811.

Eyrolle F., Antonelli C., Raimbault P., Boullier V., Arnaud M. (2010) SORA: a high frequency flux monitoring station at the lower Rhône River. In: Proceedings of the 39th CIESM Congress, Venice, Italy, 10-14 May 2010, http://www.ciesm.org/online/archives/ abstracts/index.htm

Eyrolle F., Renaud Ph. (2012) Qualité radiologique des eaux du canal Bas-Rhône-Languedoc, Synthèse de connaissances, Mise en perspective historique et régionale, rapport final, Report IRSN PRPENV/SESURE/2012-07.

Eyrolle F., Radakovitch O., Raimbault P., Charmasson C., Antonelli C., Ferrand E., Raccasi G., Aubert D., Gurriaran R. (2012) Consequences of hydrological events on suspended sediment and associated radionuclide deliveries from the Rhône River towards the Mediterranean Sea, Journal of Soils and Sediments 12, 1479-1495.

Eyrolle-Boyer F., Renaud Ph., Tournieux D., Zebraki M., Cossonnet C., Cagnat X. (2012) Assessment of the Radiological quality of the Rhône River waters from monitoring data at its lower course, 9th International Congress of GRUTTEE, 29-31 October 2012, Aix en Provence, France.

Eyrolle-Boyer F., Claval D., Antonelli C., Tournieux D., Cossonnet C. (2013) 1963-2013: Fifty years of anthropogenic tritium in our environment - Focus on the Rhône valley (South east France), In: 10th International Conference on Tritium Science and Technology, "TRITIUM 2013", 21-25 October 2013, Nice Acropolis France.

Ferrand E. (2010) Détermination des niveaux historiques en radionucléides et éléments traces métalliques à partir d'enregistrements sédimentaires au sein des marges alluviales du Rhône aval et de la Têt, Contribution au projet ANR EXTREMA (contrat $\mathrm{N}^{\circ}$ ANR-06-VULN-005-2007-2011), Post-doc report, Report DEI/SESURE 2010-02.

Ferrand E., Eyrolle F., Radakovitch O., Provansal M., Dufour S., Vella C., Raccasi G. and Gurriaran R. (2012) Historical levels of heavy metals and artificial radionuclides reconstructed from overbank sediment records in lower Rhône River (South - East France), Geochemica and Cosmochimica Acta, special Issue on Environmental Records of Anthropogenic Impacts 82, 163-182.

Filella M., Town R.M., Buffle J. (2002) Speciation in freshwaters. In: Chemical Speciation in the Environment, 2nd edn. (A.M. Ure, C.M. Davidson, Eds.). pp. 188-236. Blackwell, Oxford.

IAEA (2012) Environmental Modelling for radiation Safety (EMRAS). A 405 summary report of the results of the EMRAS Programme (2003-2007). Vol. 1678 (IAEA-TECDOC, 2012).

Laubenstein M., Magaldi D. (2008) Natural radioactivity of some red Mediterranean soils, Catena 76, 22-26.

Le Roux G. (2007) Radionucléides naturels en France. Approche géochimique de la variabilité des radionucléides naturels d'origine tellurique $\left({ }^{40} \mathrm{~K}\right.$ et chaines U-Th) dans les sols et sédiments fluviaux, Report IRSN/DEI/SESURE 2007-21.

Perkins R.W., Thomas C.W. (1980) Worldwide Fallout. In: Transuranic elements in the environment (W. C. Hanson Ed.) pp. 53-82. U.S. DOE, USA.

Picat Ph., Calmet D., Louvat D., Vray F., Lemaitre N., Linden G., Barbey P., Pigree G., Bourcier T., Levy F., Le Bar S., Baron Y., Delacroix D., Panaïva E., De Bruyne T., Hervé J.Y., Beguinel P., Cabanne N., De Paepe A., Santucci C., Prot T., Matray J.L., 
and Tillie J.L. (2002) Radioactivité d'origine naturelle dans l'environnement en France: niveaux non pertubés par l'homme, Radioprotection 37 (3), 283-327.

Porcelli D., Swarzenski P.W. (2003) The behaviour of U- and Th series nuclides in groundwater and the tracing of groundwater, Reviews in Mineralogy and Geochemistry 52, 317-361.

Pourcelot L., Vassas C. (2005) Mode de formation des placers radioactifs et origine des minéraux lourds du littoral de Camargue, Report SESURE/2005-09.
Renaud Ph., Métivier J.M., Castellier J.M., Pourcelot L., Louvat D. (2004) Cartographie des dépôts de ${ }^{137} \mathrm{Cs}$ en mai 1986 sur l'ensemble du territoire français métropolitain, Radioprotection 39 (1), 23-38.

Rolland B., Eyrolle F., Bourles D. (2006) Transfert des Radionucléides artificiels par voie fluviale : Conséquences sur les stocks sédimentaires et les exports vers la Méditerranée, Radioprotection 41 (2), 6-8.

Cite this article as: F. Eyrolle-Boyer, C. Antonelli, Ph. Renaud, D. Tournieux. Origins and trend of radionuclides within the lower Rhône River over the last decades. Radioprotection 50(1), 27-34 (2015). 